\title{
An Analysis of Twitter in the Passing of His Majesty King Bhumibol Adulyadej
}

\author{
Araya Pudtal and Sukree Sinthupinyo
}

\begin{abstract}
The passing of His Majesty King Bhumibol Adulyadej in 2016 caused phenomena of Twitter in several aspects, for example, number of tweets and retweets, semantic of tweets which were different from other events, occurrence of various small events, characteristics of retweet behavior in several groups of users, and characteristics of the distribution of users based on geolocation. To analyze these phenomena, we designed our research using Web Crawlers and Twitter Advanced Search (https://twitter.com/search-advanced) to collect and analyze tweets. We started our tweets collecting by keywords and hashtags relating to King Bhumibol Adulyadej. From the data, we have found that several events that were not the main ones are also interesting. Hence, we propose a method which can extract small events from tweets. Moreover, we analyzed users' behavior comparing to tweets in normal situations and explored the distribution based on geolocation embedded in the tweets.
\end{abstract}

Index Terms-Twitter, social media mining, clustering of tweets.

\section{INTRODUCTION}

When important moments occur, Twitter is used as a tool that can quickly initiate and largely spread information, both facts and opinions. One reason is that Twitter allows users to post message no longer than 280 characters. They do not take a long time to create a message and its retweet function can spread information more quickly than other news sources.

From the reason above, we decided to collect and analyze events related the passing of His Majesty King Bhumibol Adulyadej on 13 October 2016 which was one of the biggest moments and strongly influenced Thai people. Thai users posted messages via social media between 12-17 October 2016 more than 1.1 million messages. Most of messages presented grief and mourning of the people [1].

Our research is aimed to analyze and compare the similarities and differences, in Twitter, of the passing of His Majesty King Bhumibol Adulyadej comparing to other highly mentioned events, such as Earthquake in Haiti or the recent tsunami in Japan, etc. In each event, there would be different data distribution and characteristics. Especially, in the event we are interested, we have found that there were many small and not official event related to the main event, such as making a mourning image with a bunch of people or elephants march. We could not find these small events from the words directly related to the king. Such events could not be found if we ranked words by the number of tweets or retweets as done

Manuscript received September 30, 2017; revised November 18, 2017.

The authors are with Chulalongkorn University, Thailand (e-mail: araya.pu@student.chula.ac.th, sukree.s@chula.ac.th). in the main events. In this paper, we hence propose a novel method that can extract small and interesting events that happened on Twitter by considering the changing of the originality ratio which will be described in Section III.

\section{RELATED WORK}

Due to the outstanding characteristics of Twitter that is a form of short messages and real-time, there have been many works interested in analyzing Twitter data to find the story in each period. In the work of $\mathrm{Hu}$, et al. [2], they analyzed the influence of Twitter users, which were found that the mass media and media people would be able to report the news before other groups, but celebrities used their social power to help spread the news and stimulate discussion. Moreover, there are various works relating to the analysis of events occurring in Twitter as follows.

\section{A. Spatial Data Analysis over Time}

The analysis of spatial data based on the time they occurred has been investigated in many events, such as an analysis of the growth rate of tweets in each area and characteristics or patterns of post-message distribution on Twitter [3], an analysis of geolocation of tweets using GPS-based detection and address-based detection, such as in the case of tweets occurred in the tsunami in Japan. The location was divided into four areas, namely the disaster area, the surrounding area, the Eastern Japan area, and other areas. It was found that people in the disaster area tended to more directly communicate, exchange information and reply-tweet than other areas. On the other hand, people in the other areas retweeted the information from the disaster area. Moreover, the number of retweets would increase after the earthquake immediately, which showed that there were a lot of data being sent across Japan. [4]

Vieweg, et al. [5] analyzed the distribution of user's geolocation from the Oklahoma Grassfires of April 2009 and the Red River Floods that occurred in March and April 2009. They showed that the Oklahoma Grassfires event had distributed geographical information over the Red River Floods event. Furthermore, tweet embedded location information tended to be published more than tweets in other events.

\section{B. Content Analysis}

Oh, et al. [6] explored and analyzed rumors from Twitter data of Haiti Earthquake 2010. They used \#haitiearthquake as a keyword to collected tweets from 12-21 January 2010. They have found that related tweets were active just only a few days after the incidence, and then they gradually decreased. They also found that the characteristics of tweets corresponding to 
this earthquake were different from other events. They mostly expressed sorrow and sympathy. Moreover, the most related terms of words were "Haiti", "Earthquake" and "helpHaiti".

In a research relating to the Japan tsunami in 2011, the tweets in Japanese were compared to ones in English. Contents related to the tsunami were mostly in Japanese. This showed that the Japanese people felt worry about the tsunami, while the English tweets mostly related to the nuclear crisis. It can be concluded that the people in each different group were anxious about the different events [7].

Similarly, from the massive flood in Thailand in 2011, there was a work which analyzed content of tweets and the characteristics of Twitter users during the 2011 Thai Flood. It was found that most of the tweets involved the situational announcement and alert. They were tweeted from members of local communities. This shows the capability of Twitter which can real-time report the up-to-date information. One of the concerns in this situation was that the tweets related to assistance and news came from various sources which might be invalid and unreliable. The researchers have analyzed the reliability of Twitter users based on the number of tweets, retweets, and followers [8] .

\section{Event Analysis}

When analyzing and comparing Twitter user behavior from other events, twitter activity varies over the days of each event and a number of tweets will reflect the significance of the events in each period [9]. When analyzing the possibility of using the tweets data to detect earthquakes, they have found that Twitter could detect earthquakes faster than any other sources. Because the other sources had to wait for the actual data and being clearly identified before publishing official news. It could be analyzed and compared earthquake locations by using geo-tagged tweets [10].

Terpstra, et al. [11] analyzed the distribution of tweets that were published before and during the Pukkelpop 2011, an event in Belgium and the Netherlands. They found that the first tweets originated from the festival site and then tweets spread throughout the areas. From considering the content of tweets, they found that before the incident started, Twitter users mentioned environmental cues and expressed their high threat perceptions, but during the storm in Pukkelpop 2011, the tweets published about damage and casualty report.

From both events above, the special characteristic of events that happened in specific places can be seen. For example, the earthquake or the festival that happened in a specific place and time can be identified and analyzed by the location appeared in each tweet.

And also in the work of Marcus, et al. [12], the events were visualized and summarized using TwitInfo by the streaming algorithm in order to search for the peak of tweets automatically. This system worked well but it did not focus on finding small events or events having a small number of mention.

The passing of His Majesty King Bhumibol Adulyadej is similar and different from other events in several issues such as the number of tweets and retweets, the period that a tweet has been retweeted, the characteristics of content, the characteristics of geotagged tweets. In the period of the event of the passing of the late King, there were a lot of small events which we should pay our attention to. Hence, in this paper, we also propose a method that can detect small events mentioned by many users.

\section{Methodology}

In our research, we collected Twitter data using the web crawler and Twitter Advanced Search, from which we could search for several types of data such as a word, people, places, dates and retweet messages. We used the similar idea as in $\mathrm{Oh}$, et al. [6] by starting with keywords that were surely related to the passing of King Bhumibol Adulyadej, namely \#ในหลวง (the king) and \#ภูมิพล (Bhumibol) from 1 October 2016, to 31 December 2016. Then, the total number of hashtags in the returned results was counted. The top ten hashtags found were used as the keywords in the next round. We repeated these steps until the top ten hashtags did not change. In this experiment, the search was ended in the third round when the top ranked hashtag did not change. By this approach, each round was taken around four days. Finally, 194,368 tweets with 13,729 hashtags were collected. Moreover, the location information and the types of media that corresponded to each tweet were also collected.

The Thai language is somehow more complicated comparing to the structure of the English language. The main reason is that there are no word and sentence segmentation. Furthermore, the Thai language used in this situation has a lot of transliterations and royal terms of reverence. In Twitter, Thai users sometimes used these royal terms in correctly. Some tweets were misspelled while some royal terms were used incorrectly and different from other users. For example, for the two popular hashtags, i.e. \#ขอเป็นข้ารองบาททุกชาติไป and \#ขอเป็นข้ารองพระบาททุกชาติไป (both mean "May I be your humble servant in all my lives"), the correct royal terms of reverence are the latter but the people used both because the former was used in a popular song which describes the love of Thai people towards the king, so that both hashtags were used during that period. For these reasons, we developed a dictionary for separating Thai words, especially the royal term of reverence which was better used to analyze words and hashtags and we also created a dictionary for the stop words used in Twitter.

\section{ANALYSIS OF TWITTER DATA}

\section{A. Content Analysis from Amount of Hashtag in October 2016}

Most of the emotion from Thai people in this period was in the same direction which was mourning, sorrow, and loss of the late King who passed away. Hence, the most frequently appeared hashtags from the data we collected were selected to represent Thais' feeling in this situation.

Fig. 1 presents the hashtags that were retweeted from 1 October to 31 December 2016. The number of retweets was highest on 13 October 2016. The hashtag that got the highest retweet is \#เรารักในหลวง (we love the king) followed by \#ทรงพระเจริญ (long live the king) and \#ขอเป็นข้ารองพระบาททุกชาติไป (May I be your humble servant in all my lives). These 
hashtags present the love that Thais felt for the late King. Moreover, the most retweeted tweet is “ตอนสมเด็จย่าพระประชวร พระองค์มาเล่าให้ลูกๆ ฟังว่า สมเด็จย่าเคยรับสั่ง ตายแล้วห้ามร้องไห้ เพราะเป็นของธรรมดา คนเราก็ต้องตาย \#KingBhumibol (when the Royal Grandmother was sick, she told her kids that when she dies, do not cry because it is ordinary that every people have to die \#KingBhumibol)".

\section{B. Change of Hashtags on 13 October 2016}

Before 13 October 2016, Thai citizens were waiting for the official announcement from the government about the late King's illness condition and praying for the late King to be healthy again. At last, Thailand's beloved King has passed away on 13 October 2016. In this section, we would like to demonstrate the change of hashtags used on that day. The hashtag change is shown in Fig. 2. After 3 p.m., the tweets started changing even if there were not any formal announcement about the late King. A lot of hashtags such as \#เรารักในหลวง (we love the King), \#ทรงพระเจริญ (long live the King), etc. were unusual increased. The official statement about the passing of the King Bhumibol was announce at 19:00. At that time, the related hashtags about the late King were rapidly increased until the hashtags touched the highest point and the most popular hashtags were \#ขอเป็นข้ารองพระบาททุกชาติไป (May I be your humble servant in all my lives), \#เรารักในหลวง (we love the King) and \#ทรงพระเจริญ (long live the king), respectively (Fig. 2).

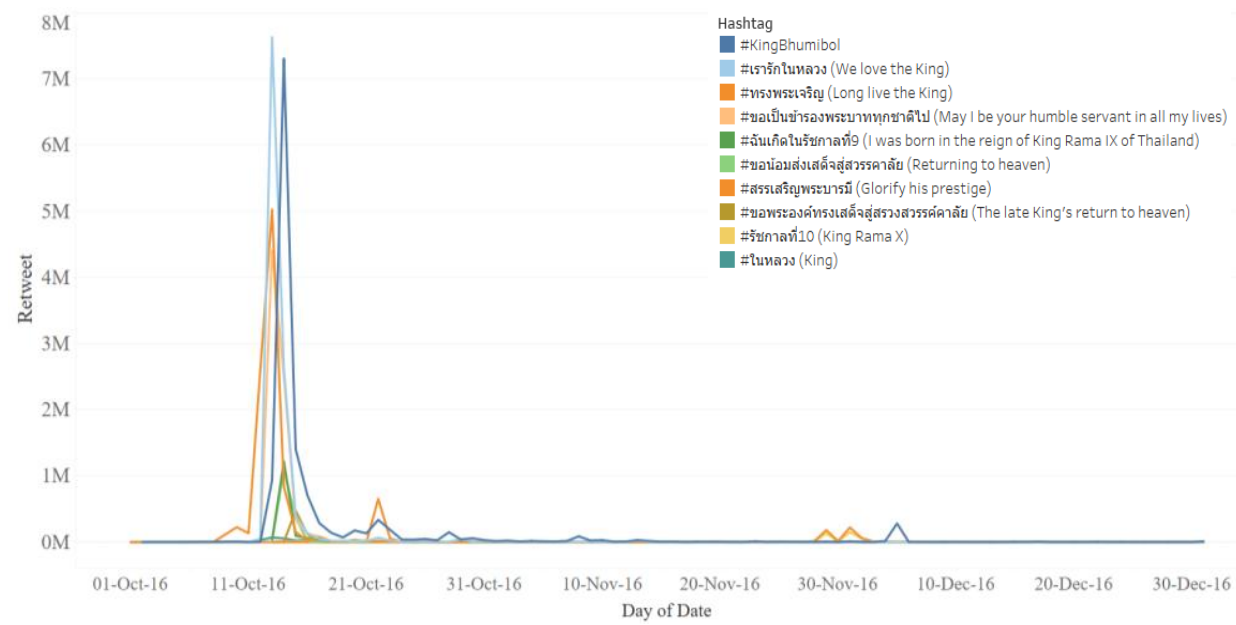

Fig. 1. Hashtag occurred during 1 October - 31 December 2016.

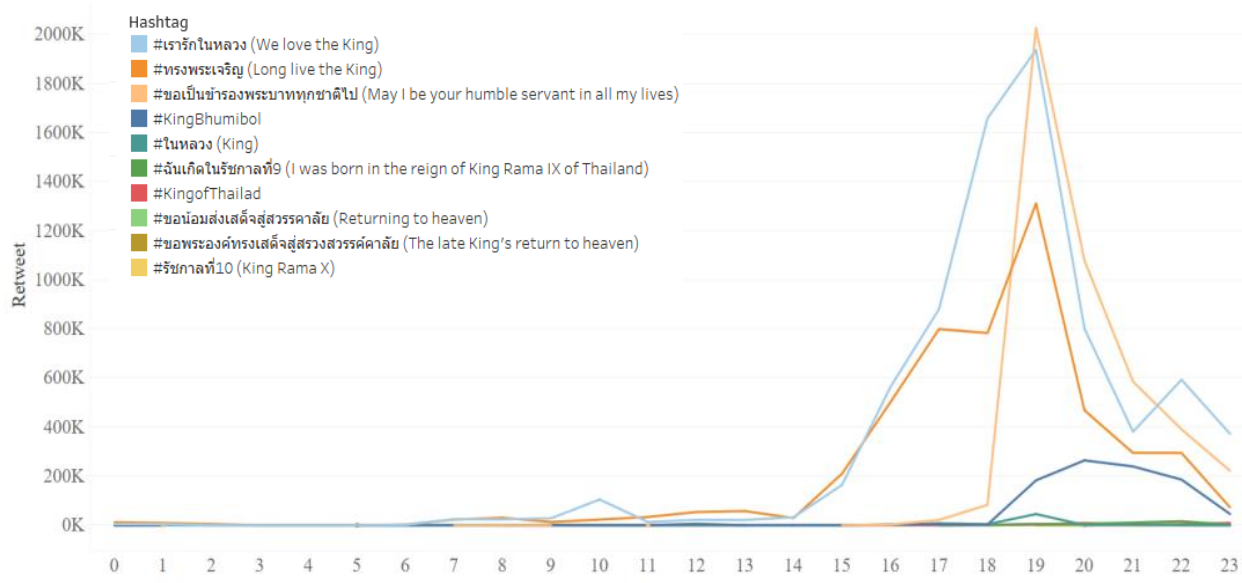

Furthermore, the number of tweets after 13 October 2016 still shows that other hashtags which were obviously high retweeted but occurred in different days. For example, on 14 October 2016 the highly retweeted hashtag was "\#KingBhumibol", on 22 October 2016 the top hashtags reteweeted were \#สรรเสริญพระบารมี (glorify his prestige) and "\#KingBhumibol", on 29 November 2016 and on 2 December 2016 the top retweeted hashtag was \#ทรงพระเจริญ (long live the king) and on 5 December 2016 (which is the King Bhumibool's birthday), the top hashtag was \#KingBhumibol, etc.

\section{Change of Hashtags after 13 October 2016}

The passing of His Majesty King Bhumibol Adulyadej was different from other incidences. The number retweets of this incidence were high and people had been keeping retweets for a while. For example, on 22 October 2016, Thais gathered to sing the royal anthem in honor of the late King at Sanamluang which influenced the peak of the related hashtags. At 1 p.m., it was the first-time slot that the crowd sang the song with the orchestra, so that this event caused the highest retweet on that day. The top hashtags were \#สรรเสริญพระบารมี (glorify his prestige) and \#KingBhumibol. At 4 p.m., it was the second time of the royal anthem song singing event that caused the high volume of hashtags in \#KingBhumibol and \#สรรเสริญพระบารมี (glorify his prestige). The third time of the song event was at 7 p.m., the hashtags occurred was \#สรรเสริญพระบารมี (glorify his prestige) and \#เรารักในหลวง (we love the King). The final round was at 10 p.m. which had these two 
hashtags \#สรรเสริญพระบารมี (glorify his prestige) and retweets and hashtags in different period are different. \#KingBhumibol. It can be seen in the Fig. 3 that the number of

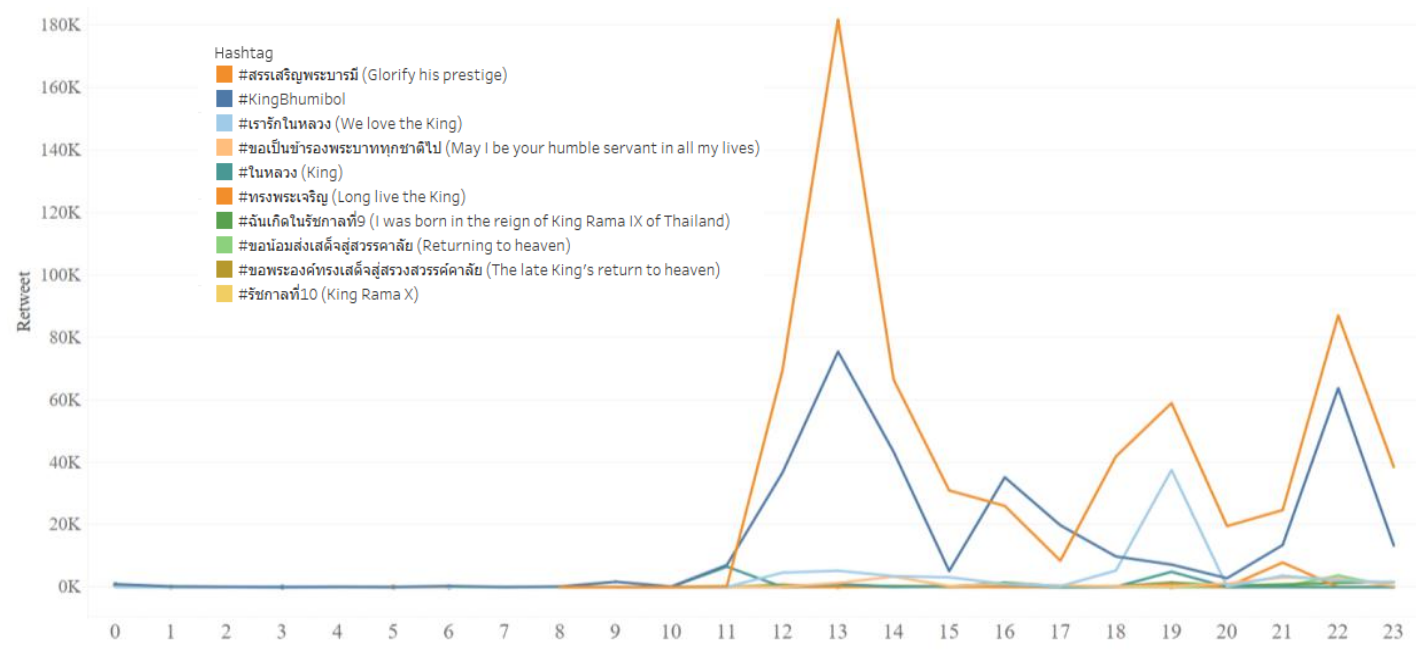

Fig. 3. Hashtag occurred in each hour on October 22, 2016.

\section{ANALYSIS OF SMALl EVENTS}

The data acquired between 1 October 2016, and 31 December 2016, show that there were many small events related to King Bhumibol Adulyadej which could be found in every single day during this period. However, these small events were unable to be easily found using the number of keywords or hashtags as in the main event. Moreover, these small events had a small number of mentioned and retweets which could not surpass the number of tweets of the main events. Due to this issue, searching using keywords or hashtags is insufficient. Hence, we propose a method to retrieve the small events by considering a ratio of the number of retweets and the number of distinct tweets of each word. Then, the words were sorted by this ratio. The most 15 frequent words are summarized in the Table I.

TABLE I: THE EVENTS BASED ON RATIO OF A NUMBER OF RETWEET AND RATIO OF A NUMBER OF TWEET THAT WORD OCCURRED.

\begin{tabular}{|c|c|}
\hline Date & Event \\
\hline 2 October 2559 & แถลงการณ์ฉบับที่ 36 (The $36^{\text {th }}$ announcement) \\
\hline 10 October 2559 & สวดมนต์ (Pray) \\
\hline 12 October 2559 & แถลงการณ์สำนักพระราชวัง (The announcement) \\
\hline 22 October 2559 & $\begin{array}{l}\text { สรรเสริญพระบารมี ท้องสนามหลวง (The royal anthem in honor of } \\
\text { the late King at Sanam Luang) }\end{array}$ \\
\hline 29 October 2559 & พระที่นั่งมหาดุสิตปราสาท (Dusit Maha Prasat Throne hall) \\
\hline 8 November 2559 & $\begin{array}{l}\text { ช้าง ถวายสักการะ พระบรมศพ (Elephants pay respects to the late } \\
\text { King) }\end{array}$ \\
\hline 9 November 2559 & จุดเทียน (Light the candle) \\
\hline $\begin{array}{l}13 \text { November } \\
2559\end{array}$ & 1 เดือน (One month) \\
\hline $\begin{array}{l}14 \text { November } \\
2559\end{array}$ & วันพระบิดาแห่งฝนหลวง (Father of Royal Rainmaking Day) \\
\hline $\begin{array}{l}15 \text { November } \\
2559\end{array}$ & แปรอักษร (Card stunts to mourn the King) \\
\hline $\begin{array}{l}29 \text { November } \\
2559\end{array}$ & รัชกาลที่ 10 ทรงพระเจริญ (Long live the King Rama X) \\
\hline 1 December 2559 & $\begin{array}{l}\text { ประกาศขึ้นทรงราชย์อย่างเป็นทางการ (Official announcement that } \\
\text { King Rama } 10 \text { has ascended as His Majesty the King) }\end{array}$ \\
\hline 4 December 2559 & พรุ่งนี้วันพ่อ (Tomorrow was Father's day) \\
\hline 5 December 2559 & วันพ่อแห่งชาติ (Father's Day) \\
\hline 31 December 2559 & $\begin{array}{l}\text { พรจากฟ้า พรปีใหม่ สวดมนต์ข้ามปี (A gift, Happy New Year and } \\
\text { pray over the year) }\end{array}$ \\
\hline
\end{tabular}

In this work, we defined the originality ratio (1) which is the ratio between and the number of retweets and the number of distinct tweets contains the words on a single day.

Three small events were founded by this equation. Table II summarizes the small events and the date of the events.

$$
\text { Originality Ratio (word) }=\frac{\# \text { retweet }}{\# \text { distinct Tweet }}
$$

where \#retweet denotes the number of retweets of the word in each day and \#distinctTweet is the number of distinct tweets in which the word occurred on each day.

TABLE II: THE EVENTS BASED ON RATIO OF A NUMBER OF RETWEET AND TWEET THAT WORD OCCURRED.

\begin{tabular}{|c|l|}
\hline Date & \multicolumn{1}{c|}{ Event } \\
\hline 2 October 2559 & แถลงการณ์ฉบับที่ 36 (The 36 ${ }^{\text {th }}$ announcement) \\
\hline 8 November 2559 & ช่วยเหลือ ท้องสนามหลวง (Help at Sanam Luang) \\
\hline 12 December2559 & $\begin{array}{l}\text { นิทรรศการภาพถ่ายในหลวง ร.9 (Photography exhibition of } \\
\text { King Rama 9) }\end{array}$ \\
\hline
\end{tabular}

However, we want to reduce the significance of events which are has a high number of mentioned or retweeted by taking the $\log$ of the number of retweets and the number of tweets containing the words, as shown in (2).

$$
\text { Originality Ratio }=\frac{\log (\# \text { retweet })^{\alpha}}{(\# \text { tweet })^{\beta}}
$$

where \#retweet denotes the number of retweets of the word in each day, \#tweet represents the number of tweets that the word occurs on each day, and $\alpha, \beta$ are integers $(\alpha, \beta>=0)$.

In our experiments, we found that when $\beta$ increases and $\alpha$ decreases we can obtain a high number of small events. Moreover, the most 15 frequent words can be categorized and classified to the small events more clearly because the tweets with a high number of retweets are reduced its significance. Thus, the tweets which have a small number of retweets are significantly influenced. However, when $\alpha$ is greater than $\beta$, some of the small events could be missed. Table III summarized the small events corresponding to the value of $\alpha$ and $\beta$.

In conclusion, our proposed method can detect the small events which are less relevant to the main events but have a 
high number of retweets effectively.

TABLE III: COMPARISON OF ALPHA AND BETA TO FIND SMALL EVENTS

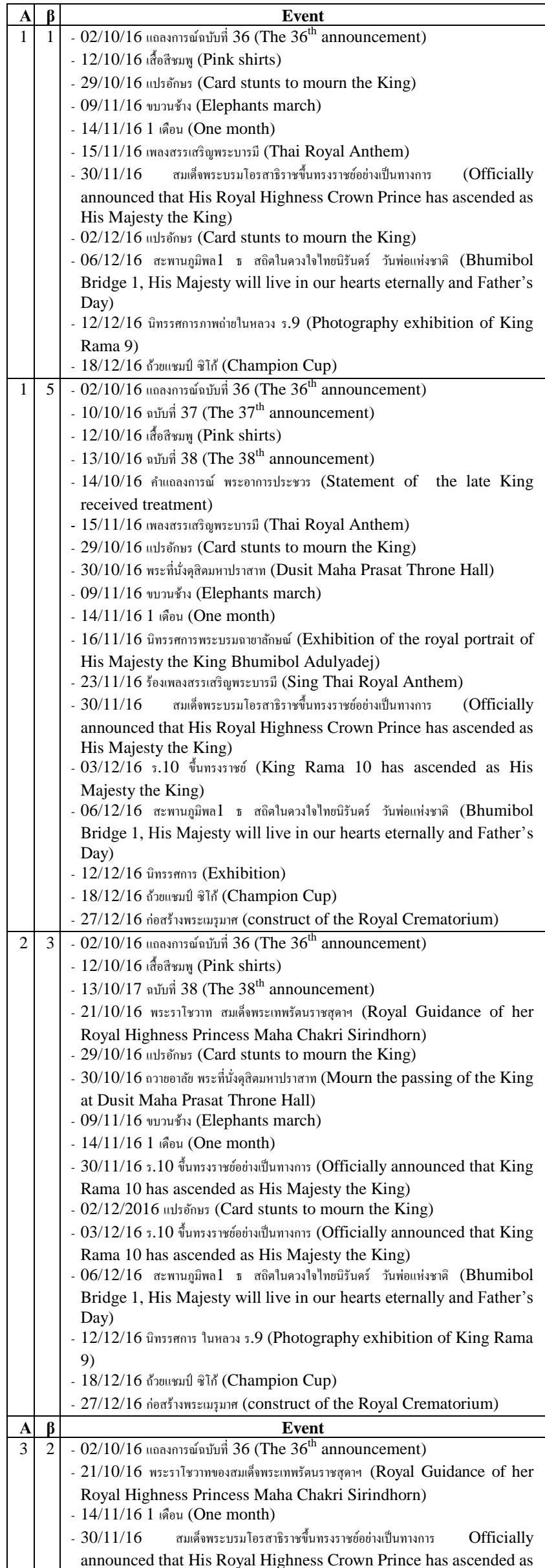

\begin{tabular}{|c|c|c|}
\hline & & $\begin{array}{l}\text { His Majesty the King) } \\
\text {-02/12/2016 แปรอักษร (Card stunts to mourn the King) } \\
\text {-03/12/16 ร.10 ขึ้นทรงราชย์ (King Rama } 10 \text { has ascended as His } \\
\text { Majesty the King) } \\
\text {-06/12/16 สะพานภูมิพล } 1 \text { ธ สถิตในดวงใจไทยนิรันดร์ วันพ่อแห่งชาติ (Bhumibol } \\
\text { Bridge } 1 \text {, His Majesty will live in our hearts eternally and Father's } \\
\text { Day) } \\
\text { - 12/12/16 นิทรรศการภาพถ่าย ในหลวง ร.9 (Photography exhibition of King } \\
\text { Rama 9) } \\
\text { 18/12/16 ถ้วย (Trophy) } \\
\text { - } 31 / 12 / 16 \text { พระบรมศพ ท้องสนามหลวง (His Majesty The King's body at } \\
\text { Sanam Luang) }\end{array}$ \\
\hline 4 & 1 & $\begin{array}{l}\text { 02/10/16 แถลงการณ์ฉบับที่ } 36 \text { (The } 36^{\text {th }} \text { announcement) } \\
\text { 21/10/16 สมเด็จพระเทพรัตนราชสุดาฯ (Her Royal Highness Princess Maha } \\
\text { Chakri Sirindhorn) } \\
\text { - 12/12/16 นิทรรศการภาพถ่าย ในหลวง ร.9 (Photography exhibition of King } \\
\text { Rama 9) } \\
-31 / 12 / 16 \text { สวดมนต์ข้ามปี ท้องสนามหลวง (Pray over the year at Sanam } \\
\text { Luang) }\end{array}$ \\
\hline 5 & 1 & $\begin{array}{l}-02 / 10 / 16 \text { แถลงการณ์ฉบับที่ } 36 \text { (The } 36^{\text {th }} \text { announcement) } \\
-12 / 12 / 16 \text { นิทรรศการภาพถ่าย ในหลวง ร.9 (Photography exhibition of King } \\
\text { Rama 9) } \\
-31 / 12 / 16 \text { ท้องสนามหลวง (Sanam Luang) }\end{array}$ \\
\hline
\end{tabular}

\section{RETWEET BEHAVIOR}

From the analysis of influence Twitter users, which found that the mass media and media people would be able to report the news before other groups, but celebrities used their social influence to help spread the news and stimulate discussion as in [2]. We considered the change of the number of retweets taken place in the passing of King Rama 9 comparing to the number of retweet in the normal events. In this section, we demonstrate user's retweet behavior by each group of users. We ranked the users from the event of passing of King Bhumibol Adulyadej by their number of followers and then collected the users' latest 200 tweets to be a sample of the normal tweets. We analyzed and compared the behavior of users' tweets during the event of the passing of King Bhumibol Adulyadej and the normal events by dividing the group of these influencers into six groups, i.e. entertainment media, news media, writer, journalists, celebrities, and others.

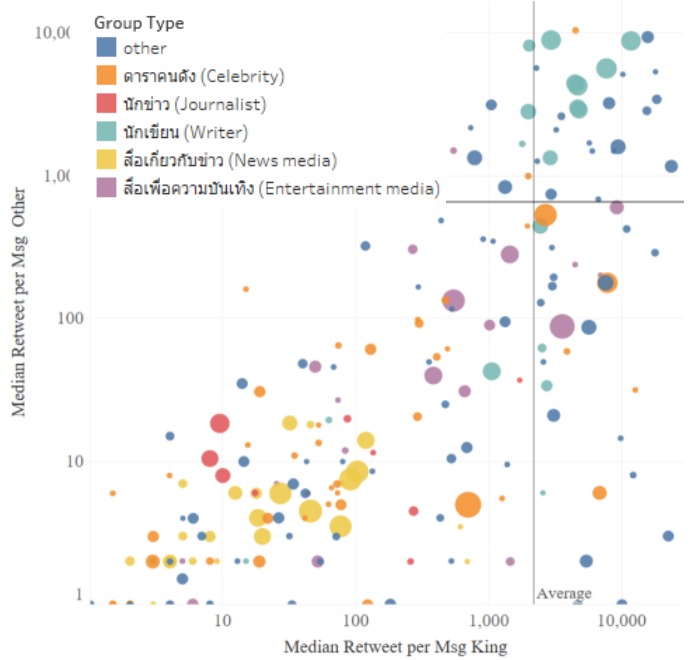

Fig. 4. Retweet behavior in the event of King Bhumibol Adulyadej comparing to normal events.

The results of the segmentation show that the news media and journalists have a low number of retweets in both normal events and the event of the passing of King Bhumibol Adulyadej. Albeit the writers (the blue-green dots in the 
top-right quadrant of the graph) have many retweets in both events. We also found that there were few users who tweeted in normal events more than the event of the passing of King Bhumibol Adulyadej. This shows that most users focused on the passing of the king and tweeted more frequent than the normal events. Therefore, by considering the correlation of users' retweet behavior in each group, we found that news media group has the highest correlation at 0.57 .

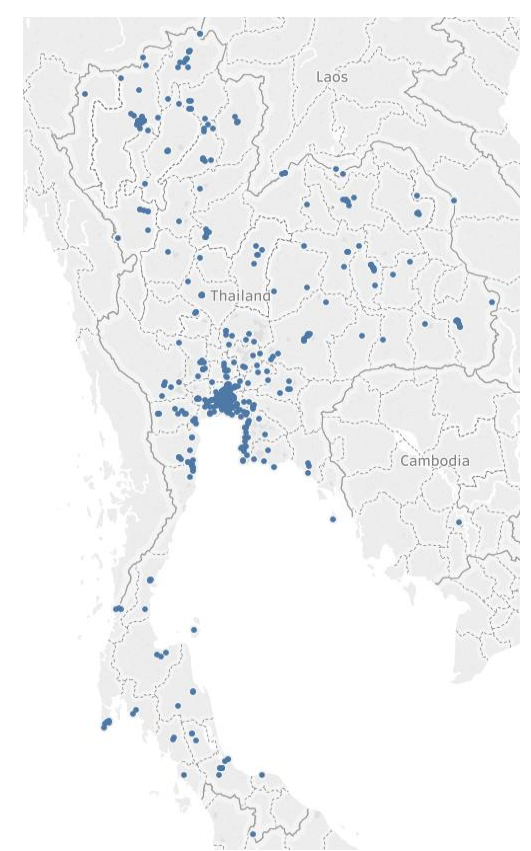

Fig. 5. User distribution in the event of King Rama 9 based on their geolocation.

\section{GEOLOCATION TWITTER}

We gathered and analyzed the geolocation data of this event and compared to earthquake or tsunami events. We have found around 2,000 tweets that embeded the geolocation data. The location of tweets are plotted on the map and show in Fig. 5. The map shows that the localtions of tweet are mainly in Bangkok and also other major cities such as Phetchaburi, Prachap Khiri Khan, and the Eastern big cities like Pattaya and Chonburi as shown in Fig. 5.

\section{TEXT CLUSTERING}

To find correlation and similarities of tweets during 1 October to 31 December 2016, we selected the K-means algorithm which is an effective and simple clustering algorithm and suitable for big data to cluster the tweets. The experiments were conducted by Weka [13]. We used the $\mathrm{K}$-means algorithm to partition data into k groups (clusters). In our experiment, Euclidean distance was used as a metric to compute centroid clusters. The results show that we can group tweets into five groups. To demonstrate the centroid of each cluster, we selected the top ten words from each group and find the tweet that contains most of these top ten words. In the case that the tweets contain the same number of top ten words we will select the shorter tweet. We found that the centroid of each group can represent the feelings of Thai people towards the King Bhumibol Adulyadej. This demonstrated love, good memory, grief, and proud to be born in the land of Thailand as shown in Table IV.

TABLE IV: SUMMARIZED THE TOP 10 WORDS FROM EACH GROUP AND AN EXAMPLE TWEET IN EACH GROUP

\begin{tabular}{|c|c|c|}
\hline$\underset{\mathbf{r}}{\text { Cluste }}$ & Word & Example of Tweet \\
\hline 1 & $\begin{array}{l}\text { เทวดา (deity) สวรรค์ (paradise) สู่ (to) กลับ (return) } \\
\text { บน (on) เสด็จ (go) สวรรคาลัย (paradise) ท่าน (you) } \\
\text { พ่อ (father) สรวงสวรรค์ (paradise) }\end{array}$ & $\begin{array}{l}\text { เทวดาของแผ่นดินไทยเสด็จกลับสู่สรวงสวรรค์แล้วภูมิใจที่ลูกได้เกิดบนแผ่นดินพ่อ \#ขอเป็นข้ารองพระบาททุกชาติไป (The deity of } \\
\text { Thailand (the late King) had returned to the paradise. We proud to be born in the land of the late } \\
\text { King \#ขอเป็นข้ารองพระบาททุกชาติไป (May I be your humble servant in all my lives).) }\end{array}$ \\
\hline 2 & $\begin{array}{l}\text { ร้องเพลง (sing) สรรเสริญพระบารมี (Sansoen Phra } \\
\text { Barami) สนามหลวง (Sanam Luang) สรรเสริญ } \\
\text { (glorify) จุดเทียน (lighted candle) ชาติ (nation) } \\
\text { ร้อง (sing) } 22 \text { ตอน (part) ท้อง (local) }\end{array}$ & $\begin{array}{l}\text { การร้องเพลงสรรเสริญ กำหนดเดิมเวลา } 14.00 \text { และ } 16.00 \text { น. ยกเลิกแล้วนะคะ ..รออีกรอบคือจุดเทียนตอน } 22.00 \text { น. } \\
\text { ที่ท้องสนามหลวงเลย \#สรรเสริญพระบารมี (The schedule of singing Sansoen Phra Barami at } 2 \text { and } 4 \text { p.m. were } \\
\text { canceled. The next round would be at } 10 \text { p.m. sing the song with lighted candle at Sanam Luang } \\
\text { \#สรรเสริญพระบารมี (glorify his prestige).) }\end{array}$ \\
\hline 3 & $\begin{array}{l}\text { พ่อ (father) รัก (love) ลูก (child) ตลอดไป (forever) } \\
\text { เหนื่อย (tired) ท่าน (the king) อยู่ในใจ (in my heart) } \\
\text { หนู (I) คนไทย (Thai) ทุกคน (everyone) }\end{array}$ & $\begin{array}{l}\text { พ่อเหนื่อยมามากพอแล้ว พักให้สบายนะพ่อ ต่อไปนี้ไม่มีอีกแล้วพ่อของแผ่นดินไทย แต่ท่านจะยังอยู่ในใจของคนไทยตลอดไป หนู รัก ในหลวง } \\
\text { \#เรารักในหลวง (The King had been tired enough, but you will still be in the mind of the Thai people } \\
\text { forever, I love you. \#เรารักในหลวง (we love the king).) }\end{array}$ \\
\hline 4 & $\begin{array}{l}\text { ในหลวง (king) พระองค์ ทรง มัน คน (person) ท่าน } \\
\text { (you) วันนี้ (today) ดู (watch) ใจ (heart) ร้องไห้ } \\
\text { (cry) }\end{array}$ & $\begin{array}{l}\text { \#wiranloveking ในหลวงทรงเปิดไฟในรถให้ทุกคนได้เห็นพระองค์ แล้วโบกมือ ทุกคนร้องไห้ หัวใจเราพองโตมาก ไม่รู้าำไมเหมือนกัน } \\
\text { มันตื้นตันไปหมด (\#wiranloveking The light in the car was turned on. Thai people could see the King } \\
\text { who was waving his hand. All Thais were crying with rejoicing and delight.) }\end{array}$ \\
\hline 5 & $\begin{array}{l}\text { เกิด (born) ภูมิใจ (proud) รัชกาลที่9 (Rama 9) ลูก } \\
\text { (child) แผ่นดิน (land) คนไทย (Thai) โชคดี (lucky) } \\
\text { พ่อ (father) ดีใจ (glad) บน (on) }\end{array}$ & $\begin{array}{l}\text { ภูมิใจที่เกิดบนแผ่นดินไทย ภูมิใจที่เกิดในรัชกาลที่ } 9 \text { ภูมิใจที่ได้เกิดเป็นลูกพ่อ เป็นคนไทย \#LongLiveTheKing (Thai people } \\
\text { proud to be born in the land of Thailand, proud to be born in the reign of the King Rama 9, proud } \\
\text { to be Thais and prouder to had that King. \#LongLiveTheKing.) }\end{array}$ \\
\hline
\end{tabular}

\section{CONCLUSION}

Many works have analyzed tweets on a variety of aspects, for example, the analysis of the influence of Twitter users [2], the distribution of geolocation [4], [5], and the analysis of the content of tweets about the tsunami in Japan [7], etc. In this paper, we collected Twitter data relating to the passing of His Majesty King Bhumibol Adulyadej from 1 October - 31 December 2016.

From the hashtags, we found that most of Thais feeling were mourning, sorrow and loss of the late King who has passed away. On 13 October 2016, there was the highest number of retweets, that was \#เรารักในหลวง (we love the king),
\#ทรงพระเจริญ (long live the king), and \#ขอเป็นข้ารองพระบาททุกชาติไป (I do be your loyal attendant in all my lives). So that the number of retweets depends on the events occurred on different days and there also were various small events related to King Bhumibol Adulyadej which could be found in every single day during this period. We detected the small events using the change of the originality ratio which is a ratio between the number of retweets and the number of distinct tweets contains the words on a single day

And when considering the influencers, we found that the news media and journalists have a low number of retweets in both normal events and the event of the proposed event but 
the writers had many retweets in both events. Most users focused on the passing of the late king and tweeted more frequent than the normal events. Moreover, most of tweets were in Bangkok and other major cities such as Phetchaburi, PrachapKhiri Khan etc. We could cluster tweets into five groups, which represented the feeling of love, good memory, grief, and proud to be born in the land of Thailand.

\section{REFERENCES}

[1] Tangsiri. (2016). Social Media Trend of Mourning for the Late Thai King. Available: https://brandinside.asia/social-mood-12-17-oct/

[2] M. Hu, S. Liu, F. Wei, Y. Wu, J. Stasko, and K.-L. Ma, "Breaking news on twitter," presented at the SIGCHI Conference on Human Factors in Computing Systems, Austin, Texas, USA, 2012.

[3] A. Java, X. Song, T. Finin, and B. Tseng, "Why we twitter: understanding microblogging usage and communities," presented at the 9th WebKDD and 1st SNA-KDD 2007 workshop on Web Mining and Social Network Analysis, San Jose, California, 2007.

[4] M. Miyabe, A. Miura, and E. Aramaki, "Use trend analysis of twitter after the great east japan earthquake," presented at the ACM 2012 Conference on Computer Supported Cooperative Work Companion, Seattle, Washington, USA, 2012.

[5] S. Vieweg, A. L. Hughes, K. Starbird, and L. Palen, "Microblogging during two natural hazards events: what twitter may contribute to situational awareness," presented at the SIGCHI Conference on Human Factors in Computing Systems, Atlanta, Georgia, USA, 2010.

[6] O. Oh, K. H. Kwon, and H. R. Rao, "An exploration of social media in extreme events: Rumor theory and twitter during the Haiti Earthquake 2010," International Conference on Information Systems (ICIS), 2010, p. 231.

[7] S. Doan, B.-K. H. Vo, and N. Collier, "An analysis of twitter messages in the 2011 Tohoku Earthquake," in Proc. 4th International Conference on Electronic Healthcare, Málaga, Spain, November 21-23, 2011, pp. 58-66.

[8] A. Kongthon, C. Haruechaiyasak, J. Pailai, and S. Kongyoung, "The role of Twitter during a natural disaster: Case study of 2011 Thai Flood," in 2012 Proc. PICMET '12: Technology Management for Emerging Technologies, 2012, pp. 2227-2232.
[9] A. L. Hughes and L. Palen, "Twitter adoption and use in mass convergence and emergency events," International Journal of Emergency Management, vol. 6, p. 248, 2009.

[10] P. Earle, M. Guy, R. Buckmaster, C. Ostrum, S. Horvath, and A. Vaughan, "OMG earthquake! Can twitter improve earthquake response?" Seismological Research Letters, vol. 81, pp. 246-251, 2010.

[11] T. Terpstra, R. Stronkman, a. D. Vries, and G. L. Paradies, "Towards a realtime Twitter analysis during crises for operational crisis management," presented at the 9th International Conference on Information Systems for Crisis Response and Management, ISCRAM 2012, Vancouver, BC, USA, 2012.

[12] A. Marcus, M. S. Bernstein, O. Badar, D. R. Karger, S. Madden, and R. C. Miller, "Twitinfo: aggregating and visualizing microblogs for event exploration," presented at the SIGCHI Conference on Human Factors in Computing Systems, Vancouver, BC, Canada, 2011.

[13] M. Hall, E. Frank, G. Holmes, B. Pfahringer, P. Reutemann, and I. H. Witten, "The WEKA data mining software: An update," SIGKDD Explor. Newsl., vol. 11, pp. 10-18, 2009.

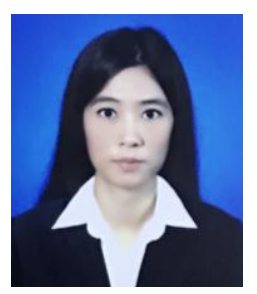

Araya Pudtal was born in 1990 in Ratchaburi, Thailand. She received the bachelor's degree in computer science from Kasetsart University in 2012. Now she is a master student in Chulalongkorn University. Her research interests are Big Data Analysis, Social Media Mining and data visualization.

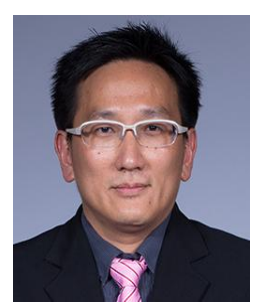

Sukree Sinthupinyo was born in 1975 in Bangkok, Thailand. He received his bachelor's, master's, and doctoral degree from the Department of Computer Engineering, Chulalongkorn University. Now he is working as a lecturer at the same department. His research interests are Artificial Intelligence, Machine Learning, Innovation, Social Network Analysis and Social Network Mining. 